\title{
Four new reports of mammal species from Tayrona National Park, Colombia
}

\author{
Alexandra Pineda-Guerrero \\ Nelson Institute for Environmental Studies, University of Wisconsin-Madison, 550 North Park St. Madison, United States \\ of America \& ProCAT Colombia, Bogotá, Colombia. pinedaguerre@ wisc.edu

\section{Elkin Hernández} \\ Parque Nacional Natural Tayrona, Dirección Territorial Caribe, Calle 17 4-06 Santa Marta, Colombia
}

Tayrona National Park (TNP) is located in Northern Colombia in the Caribbean region (Figure 1). The park is one of the 59 protected areas in the country, and was declared as World Natural Heritage Area by UNESCO (López et al. 2008). TNP covers approximately 19,256 ha and ranges from sea-level up to $900 \mathrm{~m}$ asl (Latorre et al. 2014; Figure 1). Because of its location in the transition zone between tropical dry and moist forests and the presence of thorny scrublands and cloud forests formations, TNP harbors a unique sample of the Caribbean biodiversity of Colombia (UAESPNN \& ProCAT Colombia 2012).

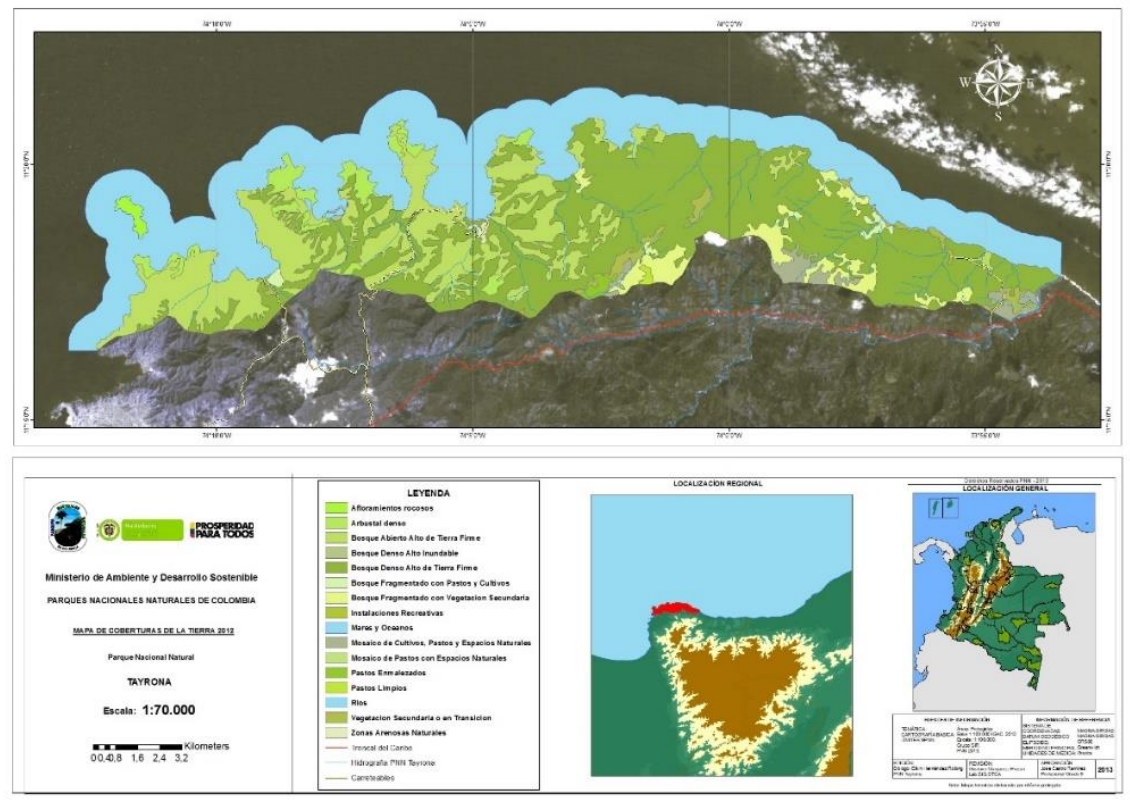

Figure 1. Location of Tayrona National Park, Colombia

This protected area is one of the most visited in the country. However, information regarding basic biodiversity inventories and especially for mammals is scarce (Jimenez-Alvarado et al. 2015). We present the first record for four species at TNP: porcupine (Coendou sp.), Brown-eared Woolly Opossum (Caluromys lanatus), Three-toed Sloth (Bradypus variegatus) and Neotropical otter (Lontra longicaudis). Reports came from sporadic encounters with park rangers and with the local community during 2014 and 2015. All individuals were juveniles and were found in different sectors in TNP. The Woolly Opossum $\left(11^{\circ} 17^{\prime} 21.35^{\prime \prime N}, 73^{\circ} 54^{\prime} 38.98^{\prime \prime} \mathrm{W}\right)$ and the Three-toed Sloth $\left(11^{\circ} 17^{\prime} 49.83^{\prime \prime N}, 73^{\circ} 54^{\prime} 56.13^{\prime \prime} \mathrm{W}\right)$ were found in the Zaino sector and the Porcupine ( $\left.11^{\circ} 18^{\prime} 29.35^{\prime \prime} \mathrm{N}, 73^{\circ} 55^{\prime} 52.95^{\prime \prime} \mathrm{W}\right)$ and Otter $\left(11^{\circ} 18^{\prime} 59.91 " \mathrm{~N}, 73^{\circ} 57^{\prime} 5.92^{\prime \prime} \mathrm{W}\right)$ in the Cañaveral sector. The Neotropical otter is associated with Piedras River and Lake Cañaveral in the park, and has been observed in Trompitos vereda, buffer zone of TNP.

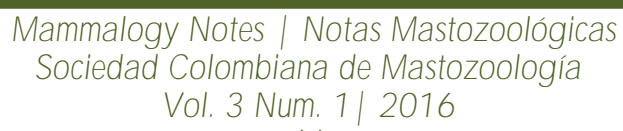




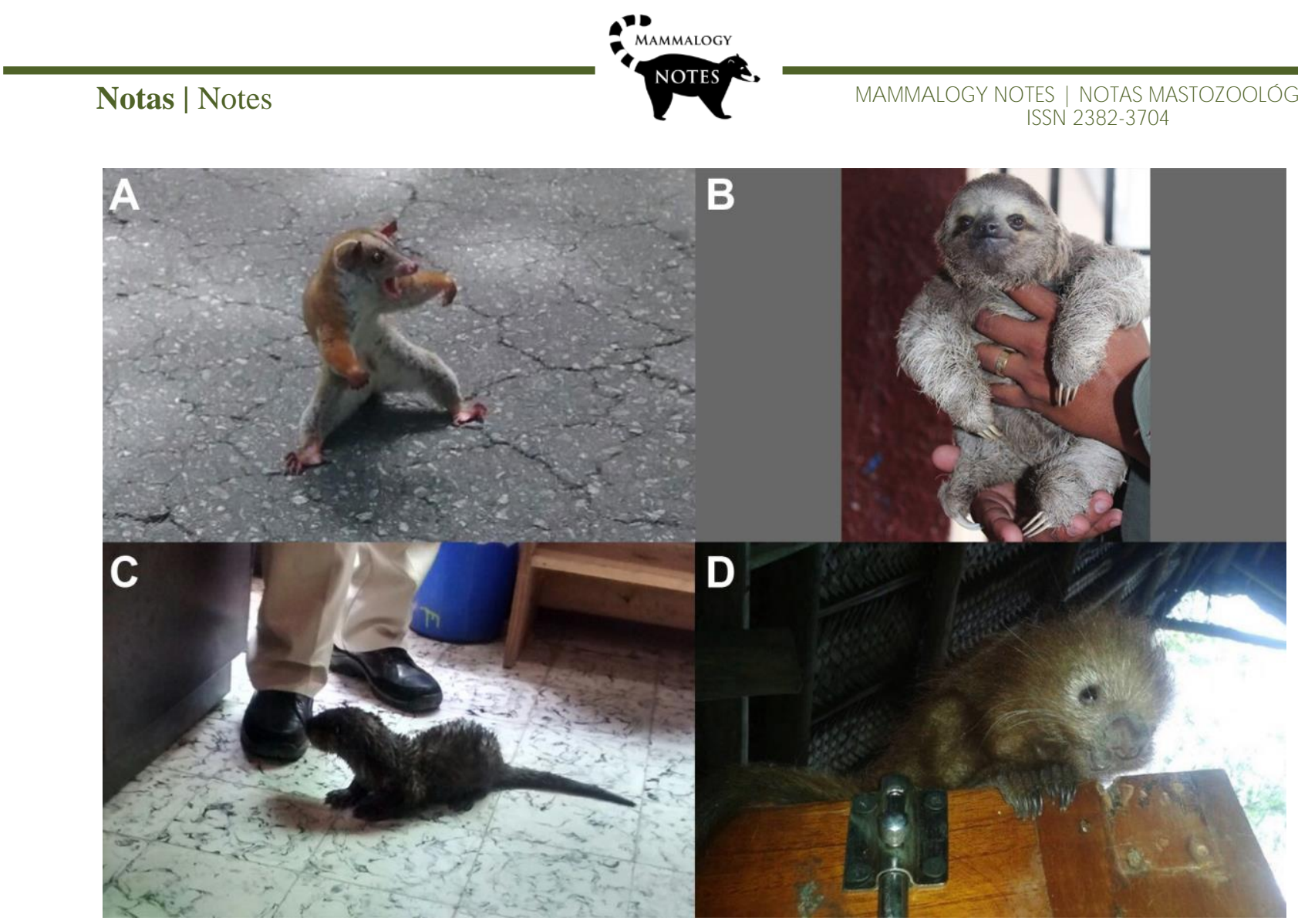

Figure 2. Four new reports of mammals for Tayrona National Park, Colombia. A. brown-eared woolly opossum (Caluromys lanatus); B. Three-toed sloth (Bradypus variegatus); C. Neotropical otter (Lontra longicaudis); D. Porcupine (Coendou sp.).

There are eight previous studies related to mammals in TNP, one management plan for the area and one systematic inventory of mammals, all of them between 1981 and 2012 (Sánchez-Herrera et al. 2006, García-Villareal 2010, Pérez-Castillo 2012, Jimenez-Alvarado et al. 2015). The most updated inventory of flying, medium, and large mammals of TNP reported 49 mammal species (Jimenez-Alvarado et al. 2015); with our report, the number of mammals at TNP increases to 53 species.

There are no historical records for these four species in TNP. Hence, these reports contribute to the knowledge of Tayrona National Park species and indicate the need to continue ecological studies in the area, including the effects of tourism on fauna. Previous studies have used camera trap methods (UAESPNN \& PROCAT COLOMBIA 2012) and the species recently reported are arboreal, therefore, further studies in arboreal species are recommended.

\section{Acknowledgment}

We thank to N. Mendez and A. Arevalo for pictures and A. Suarez for his collaboration.

\section{References}

GARCÍA-VILLAREAL. 2010. Densidad de una población introducida del tití cabeciblanco (Saguinus oedipus) en el Parque Nacional Natural Tayrona y su relevancia en la conservación de la especie en Colombia. Bogotá, Colombia.

JIMÉNEZ-ALVARADO J. S, et al. 2015. Inventory of flying, medium and large mammals from Parque Nacional Natural Tayrona, Magdalena, Colombia. Mammalogy Notes 2: 36-39.

LATORRE, J. P., et al. 2014. Atlas del Sistema Nacional de Áreas Protegidas Continentales de Colombiano. Parques Nacionales Naturales.

LÓPEZ, T., J. F., et al. 2008. Biodiversity and Cultural Conservation in Sierra Nevada de Santa Marta, Colombia. Mountain forum bulletin 8: 43-44.

PÉREZ-CASTILLO, N. 2012. Estructura y composición de los ensamblajes de murciélagos en un bosque húmedo tropical y en un bosque seco tropical en la Sierra Nevada de Santa Marta (Magdalena-Colombia). Universidad pedagógica y tecnológica de Colombia. Tunja, Colombia.

SÁNCHEZ-HERRERA, G., et al. 2006. Plan de manejo 2005-2009 Parque Nacional Natural Tayrona. Pp. 297 (Colombia PNNd ed.), Parques Nacionales Naturales de Colombia, Dirección Territorial Caribe, Santa Marta, Colombia.

UAESPNN \& PROCAT COLOMBIA. 2012. Monitoreo y creación de capacidades para la protección y manejo del Parque Nacional Natural Tayrona: enfoque en mamíferos como herramientas de planificación. pp. 185-185.

\section{Mammalogy Notes | Notas Mastozoológicas \\ Sociedad Colombiana de Mastozoología \\ Vol. 3 Num. 1| 2016}

